\title{
SEROLOGICAL PROFILE AND VIROLOGICAL EVALUATION OF HEPATITIS B AND HEPATITIS C VIRUS INFECTION AMONG HIV INFECTED PATIENTS IN GREECE
}

\author{
loannis S. Elefsiniotis ${ }^{1}$, Vassilios Paparizos ${ }^{2}$, Chrysoula Botsi ${ }^{2}$, Konstantinos D. Pantazis ${ }^{1}$, Andreas Katsambas ${ }^{2}$ \\ ${ }^{1}$ Department of Internal Medicine, Hepatology Unit, Hippokration Hospital of Athens, Athens, Greece \\ 2University Clinic, Department of Infectious Diseases, "Andreas Sygros" Hospital, Athens, Greece
}

\begin{abstract}
SUMMARY
In this study we evaluate the prevalence of HBV and HCV infections and the HBV and/or HCV viral load as well as HCV genotype among 737 HIV-infected patients. $89 / 737(12.1 \%)$ were $\mathrm{HBsAg}(+)$ and the majority of them $(60.7 \%)$ were $\mathrm{HBeAg}(+)$, in contrast to general Greek population; anti-HBc seropositivity was detected in $48.1 \%$ of the study population. Serum HBV-DNA levels were $5.75 \pm 1.66(-\log 10$ copies $/ \mathrm{ml})$ and $\mathrm{HBeAg}(+)$ coinfected patients had significantly higher levels than $\mathrm{HBeAg}(-)$ ones $(7.40 \pm 0.64$ vs $4.59 \pm 1.01$, respectively, $p<0.001) .8 .2 \%$ of HIV-infected patients were anti-HCV(+) and the majority of them (85.7\%) had HCV-RNA levels more than $700.000 \mathrm{IU} / \mathrm{l}$. The most common HCV-genotype was genotype-1 $(12 / 28,42.9 \%)$, representing a difficult-to-treat special population.
\end{abstract}

Key words: hepatitis B virus, hepatitis C virus, HIV, coinfection

Address for correspondence: I. S. Elefsiniotis, Carchidonos 9, A. Glyfada GR-16562 Greece. E-mail: ielefs@acn.gr

\section{INTRODUCTION}

Chronic viral hepatitis due to hepatitis B virus (HBV) and hepatitis $\mathrm{C}$ virus (HCV), as well as infection with human immunodeficiency virus (HIV) are global public health problems $(1,2,3)$. Liver disease caused by chronic HCV infection has now become one of the leading causes of hospital admission and death among HIV-infected patients while the incidence of classical opportunistic infections in these patients has dramatically declined as a result of potent antiretroviral therapies (ART) (3). Moreover the natural history of HBV infection is modified by coinfection with HIV (4) and the prevalence of liver cirrhosis is significantly higher in HIV/HBV coinfected patients, especially in the post-ART era (5). Finally ART-induced hepatotoxicity observed frequently in coinfected patients (6), suggesting that monitoring, prevention and, if needed, treatment of viral hepatitis in HIV-infected patients is of major importance.

\section{MATERIAL AND METHODS}

In our study we evaluated the prevalence of serological markers of HBV and HCV infections among a large group of HIVinfected patients, followed-up at a Greek center. Moreover we examined the serum levels of HBV-DNA and HCV-RNA, before the initiation of ART, in a subgroup of HIV/HBV and HIV/HCV coinfected patients respectively as well as in patients with triple (HIV/HBV/HCV) infection.

We retrospectively analyzed 737 HIV-infected patients followed-up at the Department of Infectious Diseases, "Andreas Sygros" University Hospital of Athens, Greece, since 1995, for the presence of serological markers of HBV and HCV infection.
Virological evaluation (HBV-DNA, HCV-RNA) was available in a subgroup of HIV/HBV and HIV/HCV coinfected patients, respectively. Serological markers ( $\mathrm{HBsAg}$, anti-HBs, $\mathrm{HBeAg}$, anti-HBe, anti-HBc, anti-HCV) were detected using routine commercially available enzyme immunoassays (Abbott Laboratories, Abbott Park, Illinois, USA). Serum HBV-DNA was quantified with the use of a polymerase chain reaction (PCR) assay (Amplicor, Roche, Basel, Switzerland) with a lower limit of quantification of 400 copies $/ \mathrm{ml}$. Quantitative calculation of serum HCV-RNA was done with the use of a PCR assay (Cobas Amplicor HCV test, version 2, Roche Diagnostics, Branchburg, New Jersey, USA) and detection of the principal HCV genotype was performed using INNOLIPA HCV assay (Innogenetics, Belgium). Statistical analysis of data was based on parametric methodology (Student's t-test and $\chi^{2}$ analyses, $\mathrm{p}<0.05$ ).

Overall $88.6 \%(653 / 737)$ of the study population were men and $11.4 \%$ (84/737) women; the majority of them $(453 / 737,61.5 \%)$ were homosexual (HOM) men. Thirty-nine of 737 patients $(5.3 \%)$ reported intravenous drug use (IVDU) and 17 of them were both HOM/IVDU. Twenty-two HIV-infected patients of our study population (3\%) came from endemic countries of HIV infection (EC). The rest 223 patients $(30.2 \%)$ were heterosexuals (HTS) either with $\operatorname{HIV}(+)$ sexual partners or multiple sexual partners. The modes of transmission of HIV infection in our study population are presented in Fig. 1.

\section{RESULTS AND DISCUSSION}

Among the 737 HIV-infected patients 89 (12.1\%) were HBs$\mathrm{Ag}(+)$ and the majority of them $(54 / 89,60.7 \%)$ were $\mathrm{HBeAg}(+)$ whereas $33.7 \%(30 / 89)$ of $\operatorname{HBsAg}(+) / \mathrm{HIV}(+)$ patients were 


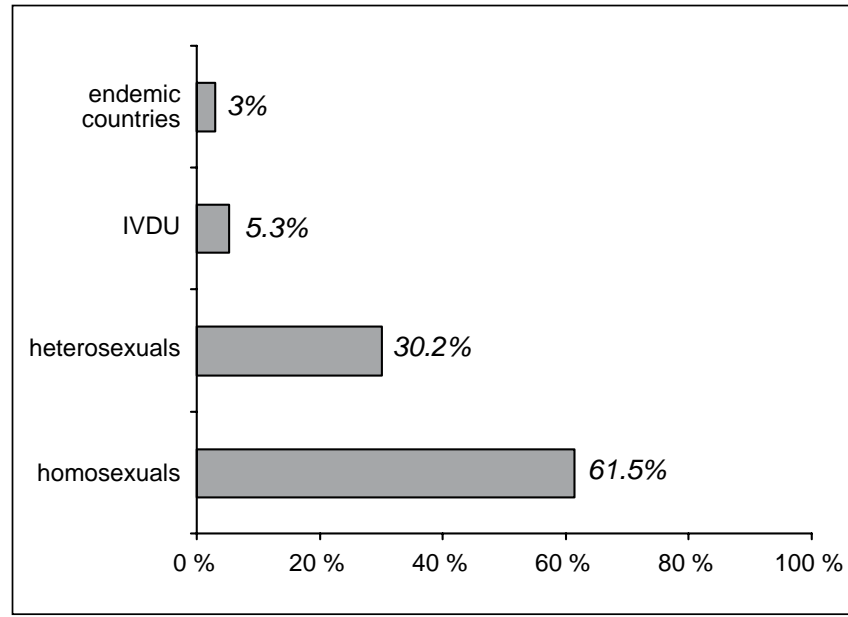

Fig. 1. Modes of transmission of HIV infection in the study population.

$\mathrm{HBeAg}(-) / \operatorname{anti}-\mathrm{HBeAg}(+)$, in contrast to general Greek population where more than $95 \%$ of chronic HBV infected patients are $\mathrm{HBeAg}$ negative (7). Five of $89 \mathrm{HIV} / \mathrm{HBV}$ coinfected patients $(5.6 \%)$ were both $\mathrm{HBeAg}(-) / \operatorname{anti}-\mathrm{HBe} \mathrm{Ag}(-)$ representing the minority of these coinfected patients. Anti-HBc seropositivity was detected in $48.1 \%(355 / 737)$ of the study population, suggesting that a great percentage of HIV-infected patients in Greece have been exposed to HBV. Serum HBV-DNA before the initiation of treatment was available in 32 of $89 \mathrm{HBsAg}(+)$ patients of

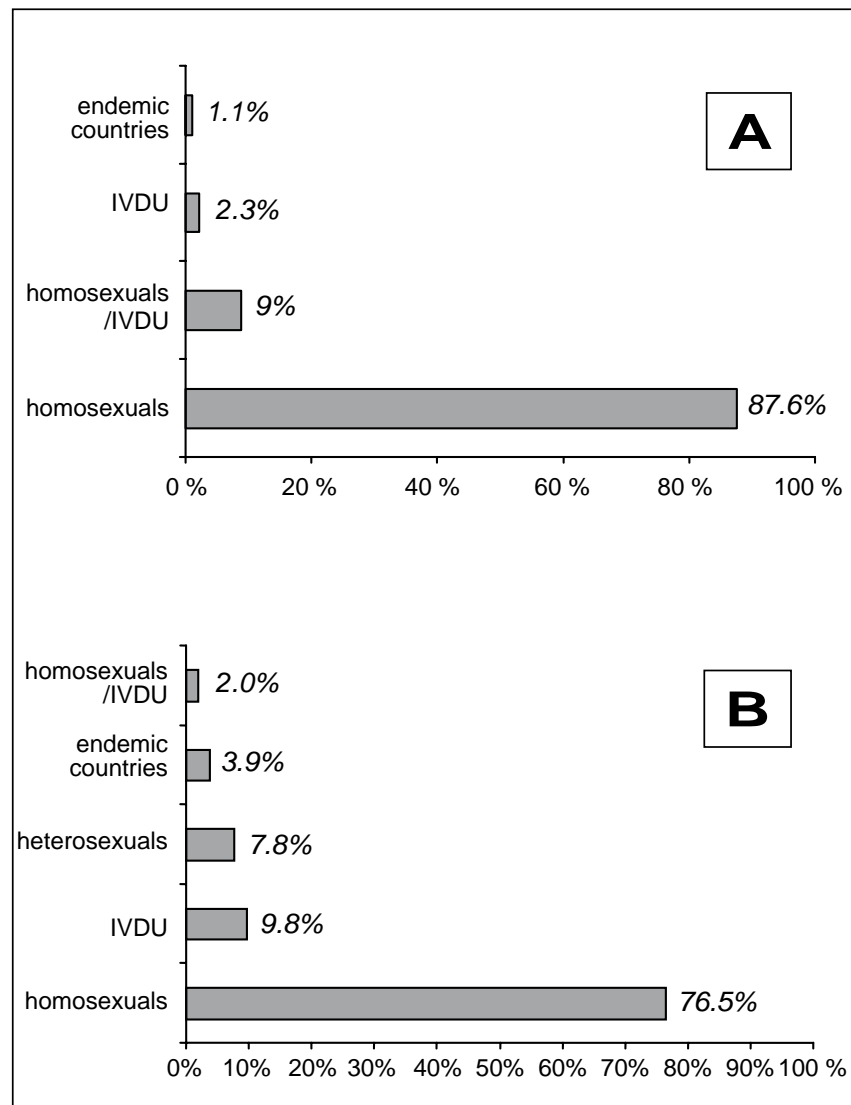

Fig. 2. Modes of transmission of HIV/HBV $(A)$ and HIV/HCV $(B)$ infections in coinfected patients of the study population. our study population. HBV-DNA levels in these patients were $5.75 \pm 1.66(-\log 10$ copies $/ \mathrm{ml})$ and $\mathrm{HBeAg}(+)$ coinfected patients had significantly higher baseline serum HBV-DNA levels than $\mathrm{HBeAg}(-) / \operatorname{AntiHBe}(+)$ coinfected ones $(7.40 \pm 0.64$ vs $4.59 \pm 1.01$, $-\log 10$ copies/ml, respectively, $\mathrm{p}<0.001)$.

The vast majority of HIV/HBV coinfected patients (78/89, $87.6 \%$ ) were HOM whereas $9 \%$ of them $(8 / 89)$ were HOM/IVDU, $2.3 \%(2 / 89)$ were IVDU and only one $(1.1 \%)$ was from an endemic African country of both infections (Fig. 2a). The proportion of HOM HIV-infected patients with chronic HBV infection $(78 / 453,17.2 \%)$ was not significantly different from that of IVDU HIV-infected patients $(2 / 22,9 \%)(\mathrm{p}=0.32)$. Among IVDU HIVinfected patients anti-HBc seropositivity was observed in $50 \%$ $(11 / 22)$ whereas none of them presented triple (HIV/HBV/HCV) infection.

Fifty-one of $625 \mathrm{HIV}$-infected patients, of which anti-HCV test was available, were anti-HCV positive ( $8.2 \%$ seroprevalence) and all of them were also HCV-RNA positive by qualitative assays. Among these HIV/HCV coinfected patients the majority (39/51, $76.5 \%)$ were HOM followed by IVDU $(5 / 51,9.8 \%)$ and HTS $(4 / 51,7.8 \%)$ whereas only two of them (3.9\%) came from EC and only one (2\%) was both HOM/IVDU (Fig. 2b). A significantly higher proportion of IVDU HIV-infected patients $(5 / 22,22.7 \%)$ than HOM HIV-infected ones (39/453, 8.6\%) as well as HTS HIVinfected ones $(4 / 233,1.7 \%)$ were also HCV-infected $(p<0.001)$, suggesting that drug abuse rather than sexual activity is the basic risk factor for HCV infection, even in HIV-infected patients.

Quantitative calculation of HCV-RNA and HCV genotyping, before the initiation of ART, were available in $28 \mathrm{HIV}(+) /$ anti$\mathrm{HCV}(+)$ patients. The vast majority of them $(24 / 28,85.7 \%)$ had HCV-RNA levels more than 700,000 IU/1 (the upper detection limit of the assay used) and the most common HCV-genotype was genotype-1 $(12 / 28,42.9 \%)$ followed by genotype-3 (10/28, 35.7\%), genotype-4 (4/28, 14.3\%) and genotype-2 (2/28, 7.1\%). All IVDU $\mathrm{HIV} / \mathrm{HCV}$ coinfected patients were infected with genotype-1 of $\mathrm{HCV}$ and exhibited extremely high viral loads (HCV-RNA>700,000 IU/l). It is also important to note that the majority of $\mathrm{HIV} / \mathrm{HCV}$ coinfected patients of our study population $(36 / 51,70.6 \%)$ were anti-HBc positive and five of them $(0.68 \%$ of the total study population $)$ were also $\mathrm{HBsAg}(+) / \mathrm{HBeAg}(+)$, exhibiting triple infection (HIV/HCV/HBV) and extremely high viral loads (HCV-RNA>700,000 IU/1, HBVDNA $>40,000,000$ copies/ml).

\section{CONCLUSION}

In conclusion, chronic HBV infection is observed in a significant proportion of HIV-infected patients in Greece, especially the $\mathrm{HBeAg}(+)$ form of the infection, resulting in high HBV viral loads and possibly high infectivity rates, in contrast to general Greek population. A great percentage of HIV-infected patients in Greece have been exposed to HBV, suggesting the need of HBV vaccination programs in $\mathrm{HBV}$ seronegatives. Chronic $\mathrm{HCV}$ infection is observed in about $8 \%$ of HIV-infected patients in our country, especially in IVDUs, whereas triple infection (HIV/HCV/HBV) is a less frequently observed finding in this population. The majority of $\mathrm{HIV} / \mathrm{HCV}$ coinfected patients in Greece are infected with genotype-1 of HCV and exhibit high serum HCV-RNA levels, representing a difficult-to-treat special population. 


\section{REFERENCES}

1. Alter MJ. Epidemiology of hepatitis C. Hepatology. 1997 Sep;26(3 Suppl 1): $62 \mathrm{~S}-5 \mathrm{~S}$

2. Life in the 21st century: a vision for all: report of the Director-General. The world health report: 1998. Geneva: World Health Organization; 1998.

3. Soriano V, Nunez M, Camino N, Garcia-Samaniego J, Puoti M, Rockstroh J. Treatment of hepatitis C in HIV-infected patients. Hepatology Rev. 2004;1(2):59-71

4. Gilson RJ, Hawkins AE, Beecham MR, Ross E, Waite J, Briggs M, McNally T, Kelly GE, Tedder RS, Weller IV. Interactions between HIV and hepatitis B virus in homosexual men: effects on the natural history of infection. AIDS. 1997 Apr;11(5): 597-606.

5. Colin JF, Cazals-Hatem D, Loriot MA, Martinot-Peignoux M, Pham BN, Auperin A, Degott C, Benhamou JP, Erlinger S, Valla D, Marcellin P.
Influence of human immunodeficiency virus infection on chronic hepatitis B in homosexual men. Hepatology. 1999 Apr;29(4):1306-10.

6. den Brinker M, Wit FW, Wertheim-van Dillen PM, Jurriaans S, Weel J, van Leeuwen R, Pakker NG, Reiss P, Danner SA, Weverling GJ, Lange $\mathrm{JM}$. Hepatitis B and C virus co-infection and risk for hepatotoxicity of highly active antiretroviral therapy in HIV-1 infection. AIDS. 2000 Dec 22;14(18):2895-902.

7. Laras A, Koskinas J, Avgidis K, Hadjiyannis SJ. Incidence and clinical significance of hepatitis B virus precore gene translation initiation mutations in e antigen-negative patients. J Viral Hepat. 1998 Jul;5(4): 241-8.

Received August 11, 2005 Received in revised form and accepted November 4, 2005 